\title{
Entrepreneurship Process and Business Incubator in Pangalengan, West Java - Indonesia
}

\author{
Zoel Hutabarat \\ Universitas Pelita Harapan \\ zoel.hutabarat@uph.edu
}

\begin{abstract}
Entrepreneurship and innovation are known as engines for growth in business especially in small and medium enterprise in Indonesia. Especially today, the Indonesian business world increasingly characterized by the presence of the creative industry is loaded with the use of technology. Growth of young entrepreneurs in Indonesia is very massive and growing increasingly diverse industry based on the hobby of businesses. The growth of creative industries supported by entrepreneurship and innovation contribute significantly to economic growth in Indonesia. On the basis of this group of youths who are members of the Indonesian Center for Sustainability Development to try to develop a business incubator in the area Pangalengan which in 2009 experienced the earthquake. Economic growth and people's lives disrupted by this disaster. In cooperation with the private sector, the group seeks to build entrepreneurial spirit to emerge from the downturn caused by natural disasters. This research tries to evaluate an effective entrepreneurship education programs in Pangalengan district in West Java province in Indonesia. The creation started with a social mapping, which reveals the characteristics and value orientation of Pangalengan people. The results of that social mapping are utilized to design a center of entrepreneurship, which will cover the whole activities of new venture creation, such as business ideas generation, training, funding, and incubation of the business.
\end{abstract}

Keywords: entrepreneurship process, technological innovation, business incubator, creative industries.

\section{INTRODUCTION}

Entrepreneurship is known as one of the drivers of economic growth because it pushes and develops innovation and creates opportunity for business. In 2016, based on Ministry of Small and Medium Enterprise, there are 58 million micro, small, and medium enterprises (MSMEs) in Indonesia (see Table I). This amount represents $99.99 \%$ of the total businesses in Indonesia and has initiated a debate whether this is good or not.

TABLE I. The NUMBer of Micro, SMALl, AND MEdium Businesses 2013

\begin{tabular}{|l|l|l|l|l|}
\hline \multicolumn{1}{|c|}{ Type } & \multicolumn{1}{|c|}{$\begin{array}{c}\text { Number } \\
\text { of } \\
\text { businesses }\end{array}$} & Percentage & $\begin{array}{c}\text { Number of } \\
\text { employee }\end{array}$ & Percentage \\
\hline Micro & 57.189 .393 & $98.77 \%$ & 104.624 .466 & $88.90 \%$ \\
Small & 654.222 & $1.13 \%$ & 5.570 .231 & $4.73 \%$ \\
Medium & 52.106 & $0.09 \%$ & 3.949 .385 & $3.36 \%$ \\
Large & 5.066 & $0.01 \%$ & 3.537 .162 & $3.01 \%$ \\
\hline
\end{tabular}

a. Source: http://www.depkop.go.id/berita-informasi/data-informasi/data-umkm/
The most frequently asked question is whether those MSMEs have the role in economic growth. Subsequently Indonesia is facing the challenges to encourage the development of more entrepreneurs who can employ many people, generate profit, and finally have their contributions to economic growth. But we can see in the Table I. how much small and medium enterprise contribute to national economic dan how many employees are work and absorb in that area. Almost 99\% of business in Indonesia supported by micro, small and medium enterprise. Businesses can not avoid them. A programme from West Java Goverment, called create 1000 entreprenuer is one of national programme to create lot of entreprenur in Indonesia. How all this programme can reach the seed of entreprenur to be a real entrepreneur especially in the rural area? Indonesia Center for Sustainability and Development (ICSD) Chapter Bandung takes the responsibility to research and implement some approach to foster entrepreneurship in Indonesia.

Indonesia Center for Sustainability and Development was held by a group of people who care about community development. This organization was focus on how to distribute corporate social responsibility programme that can reach the right people in the right time. Lot of corporate social responsibility programme from big comapanies just distribute the help or donation. This condition can make the society become lazy people and always begging for donation. This is why ICSD wanna contribute to develop the society to become more independent.

Furthermore, Indonesian government encourages the implementation of Corporate Social Responsibility (CSR) initiatives, where companies support the development of people wealth especially in the villages around the locations of companies' offices or factories. Most companies carry the programs to help people in the form of charity such as building the road, building bridges, and building places of worships.

Lately companies have shifted their focus to help the people economically by supporting them in making their own businesses either by providing financial support, knowledge transfer, or providing networking to market the products.

Pangalengan district is an area in the South of Bandung in West Java province - Indonesia, with its fertile ground for agriculture, its geothermal sources, its culture of giving services and making craft, and the proximity to city of Bandung offer a good conditional factor of the availability of human resources, big companies, and universities. The 
initiative to start a center to develop entrepreneurship, by helping the small businesses, in Pangalengan seems so natural.

This research was started at 2009 where ICSD and School of Business and Management ITB make cooperation to help and develop the society in Pangalengan whereas in 2009 this district had an earthquake and destroy almost $50 \%$ of local house and almost $80 \%$ businesses was bankrupt. This research is wanna show the development of community development programme which still run and monitor by ICSD.

\section{LITERATURE REVIEW}

\section{A. Entrepreneurship}

I take the importance by Davidsson who embraced the meaning of the Austrian business analyst Kirzner, who expressed that enterprise as "the focused practices that drive market powers". This is fascinating in light of the fact that it portrays conduct and results perspectives. Conduct angle is essential since enterprise is described by individual miniaturized scale level choice and activity. In any case, the examination on results is likewise important to see the effect of business in the general public.

The proposed meaning of enterprise will prompt the inquiry concerning who will be considered as business people and who are most certainly not. Should somebody, who opens another nourishment slow down in her or his home, be considered as a business person? As per Kirzner's definition, she or he are business visionaries since they offers new decisions for the potential clients. Merchants, who offer the materials to set up the sustenance, have new chances to supply their items. More than that few nourishment dealers in the area will feel the opposition and take vital activities, they can enhance their items, offer new administrations, or basically diminish their costs. These demonstrate the development of business sector strengths. Be that as it may, after a few times, when that "once new" sustenance merchant do her or his business routinely and stopped to make change, then the exercises get to be "the same old thing" and the individual includes can not be considered as business person any more. She or he is then just agent or specialist.

The above idea of business enterprise is about individuals conduct and their exercises in business sector connection. The last is vital in noting individuals doubt about the commitment of business to the financial advancement, which is a theme of Global Entrepreneurship Monitor (GEM) research.

Reference utilized the GEM way to deal with assess the part of business enterprise in financial development. He had recognized two sort of enterprise; need and opportunity business. Need enterprise compares to the circumstance where individuals make new organizations since they don't have different options or better alternatives and more often than not as independent work. Then again, open door enterprise speaks to the circumstance where individuals make new organizations since they need to adventure a few open doors. Reference contended that the nations with much need business can be considered as having low enterprise and in this manner contributes insignificantly to monetary development.

\section{B. Social mapping}

Social mapping is a one of strategy to recognize and to locate the relative position of individuals in financial condition. This may incorporate calling, status, size of area and family, and pay. Finding the nearby group's social quality introduction is expected to distinguish the capacity of neighborhood monetary exercises, and along these lines to outline business arranging program that are suitable with the group's conduct. This exertion get to be vital to guarantee the manageability of the project. Understanding the social quality introduction of the group is required for examining the monetary exercises that could be connected, which are in agreement with the current social condition. Additionaly some new financial frameworks can be executed without enormous disturbance to regular life.

Social mapping that is connected in the group associated with the group's social worth introduction. There are a few relations in those associations that called introduction: the connection amongst human and their life, the connection amongst human and their work, the connection amongst human and time, the connection amongst human and human, and the connection amongst human and the nature.

\section{Creative Industries}

As indicated by Irvan A. Noeman, President Director of BDA Design, an innovative item is one industry that should be produced, for example, the distro has its own specific manner to restore nearby values that exist. Conveyances are anticipated that would have the capacity to outline items that are locally however contemporary, so we\&\#39;re not simply duplicating western plans. Cases that have been effectively in particular Thailand and Japan, they have a special plan that has nearby qualities. Research from the Design Council uncovered that the configuration is turned out to be a main thrust to upgrade the aggressiveness of organizations in the UK. Setting plan as a key that has a vital part in running the business will give a decent budgetary execution, advancement sound, and cause the stream of new item improvement and administrations turn out to be more conditioned. Administrations and new items will be the main thrust of expanded intensity, quality, and efficiency (Irvan A. Noeman, 2007). Organizations that don't have the preferred standpoint of included worth regarding configuration will be stuck in the markdown field. To maintain a strategic distance from the markdown occasion that will at last prompt unreasonable rivalry, organizations ought to start to pay consideration on regarding inventiveness as an upper hand. Innovative Industries is the industry future lays on the force of human inventiveness. In the imaginative business information is key in the creation procedure and also being the driving component of the monetary advancement. On the off chance that in the previous hundreds of years area and production lines turned into the most profitable financial resource and significant wellspring of riches and success, then it is science pengetahuanlah the most essential financial resource and determinant element in making riches and success. Science is a crucial part to manufacture limit and enhance profitability, past the force of capital and work. 
Other than having incredible financial quality, the imaginative commercial ventures additionally give multiplier impacts to the improvement of different commercial enterprises related. For instance, the music business will affect the improvement of the musical instrument industry, then the impact on the recording business that will influence the industry video cuts, programming, design, modern and occasion coordinator (EO). EO industry is likewise powerful in the advancement of the tourism business, transport, lodgings and eateries (Iskandar, 2007). Multiplicative impact of the inventive commercial ventures can be found in Figure 1.

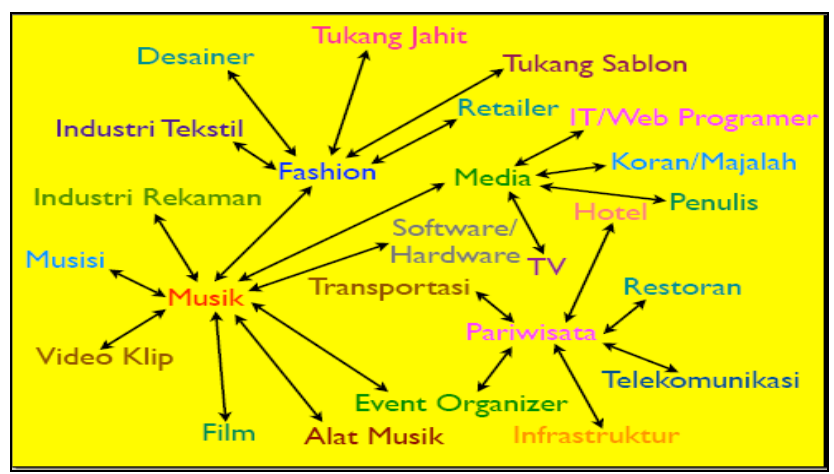

b. Ssources: Common Room Documentation, 2007

Fig. 1. Scheme of Bandung Creative Industry

Besides the economic impact, the creative industries are also able to present a variety of other positive things. Study of creative industries in the UK and other countries say that the sector is able to help foster individual fulfillment and wellbeing, uniting the nation as a community, improving the quality of education and making the country a more attractive for tourism. To determine the potential of the Creative Industries sector by sector should be measured based on the data of Gross Regional Domestic Product (GRDP) of the Central Statistics Agency (BPS), so how much percent of likely potential.

\section{RESEARCH METHOD}

The examination is done through member perception strategy, where the scientists lived in Pangalengan around 2 years, to watch the exercises and practices of the person as the individual from group. The perception was required to show the association between social quality and conduct. The perception were trailed by ethnography philosophy. The outcome would represent the social quality introduction and other information, for example, perception to the individual conduct as the individual from group.

Ethnography research produces two pictures. In the first place, the outcome will be a point of interest photo of the social circumstance. This subtle element picture portrays singular practices as indicated by point by point analyst's notes or depiction about group conduct in a few fields and clarifies about the spot, movement, and on-screen character as represented in Table 2. This photo of perception could recognize the example of activities in group.

TABLE II. DETAILED OBSERVATION OF INDIVIDUAL ACTIVITIES AND BEHAVIORS

\begin{tabular}{|l|l|l|l|}
\hline & Place & Activity & Actor \\
\hline Place & $\begin{array}{l}\text { Describe all of } \\
\text { places in the village }\end{array}$ & $\begin{array}{l}\text { Described all } \\
\text { activities those are } \\
\text { happened in that } \\
\text { place }\end{array}$ & $\begin{array}{l}\text { Described actors in } \\
\text { that place (status) }\end{array}$ \\
\hline Activ ity & $\begin{array}{l}\text { Described places } \\
\text { that activity } \\
\text { happened }\end{array}$ & $\begin{array}{l}\text { Described all } \\
\text { activities in the } \\
\text { village }\end{array}$ & $\begin{array}{l}\text { Described the actors } \\
\text { who inv olved in the } \\
\text { activity }\end{array}$ \\
\hline Actor & $\begin{array}{l}\text { Described places } \\
\text { where the actor } \\
\text { always involved }\end{array}$ & $\begin{array}{l}\text { Described the } \\
\text { activities that actor } \\
\text { involved }\end{array}$ & $\begin{array}{l}\text { Described all the } \\
\text { actors in the village } \\
\text { (status) }\end{array}$ \\
\hline
\end{tabular}

That first picture does not give the meaning of the culture that community yet. The picture of culture would be achieved when the actions of people seen based on the community itself. Therefore, the meaning of those actions or behaviors could be interpreted by the result from cultural value orientation, i.e. how community give meaning from their actions or behavior.

Next this research focused on social networking data, which is used to define the group of concerns that are happened in every social relationship, see Fig. 2. This social networking data would picture the grouping based on objects and indicate who is the dominant person in this networking. Moreover this data could tell the status and roles of the individual system in each group.

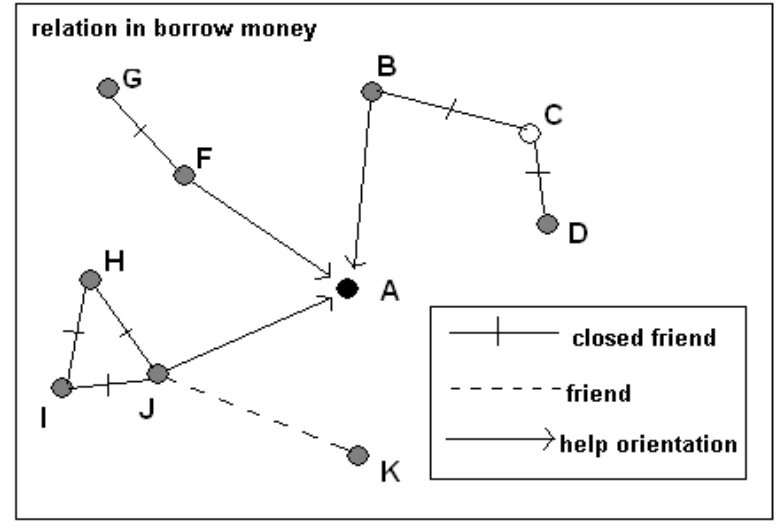

Fig. 2. The Social Networking Data 
The result from social networking analysis also be used for Focus Group Discussion between dominant persons in each social institution. Focus Group Discussion (FGD) is needed for solving the social problems that are appear in the community. FGD could inform researcher about the history of the way the community resolves its problem and might form the base for current and future solution. FGD should involve not too many people, maximum 20 persons, and the participants might include people from local government, informal leader in social institutions, non government organization, economy person as well as local entrepreneurs.

\section{RESULTS AND DISCUSSION}

\section{A. Social Mapping}

The finding in the fiels, there are two noteworthy significance action of Pangalengan individuals, one section works in the horticultural division and the other part works in the creation and administration industry. In the rural segment it self, partitioned into the proprietor of the area or area ruler and the general population who work for the lan master. A few people who develop their own ground have additionally to fill in as works in the business amid off seasons. In the administration business individuals offer carport administrations, engine taxi, and truck rent to transport the harvest or the products.

As an option people attempt to do their own business by making and offering treats and items using milk, which is one of the primary items in Pangalengan. A few people function as part-clock for these home businesses. Individuals consider the CSR programs from organizations in the area as their privilege and as a blessing. Be that as it may some philanthropy like projects to assemble physical offices have missed the target since they didn't answer the general population's need. The opposition between people or between towns to get the CSR backings is high, which frequently prompt social agitation.

Unemployment level is high, particularly in the capital of the locale, which prompts the development of road offenders that make inconveniences in focus of exercises like in the customary markets and around the transport stops. It is additionally intriguing to note that by and large the level of instruction is low and numerous young people are hitched early.

\section{B. Value Orientation}

The following orientations are identified at Pangalengan:

The essence of relation between human and their life. The social estimation of the group is situated toward a dependancy on the characteristic and the trust that life is simple. Thusly they simply need to carry on with the life as it may be. They are appreciative to their surroundings (nature). This condition drives the neighborhood group to acknowledge the condition and has an identity that can be depicted as good faith without working.

The essence of relation between human and their work. Individuals consider fill in as an endeavor to keep up the great life. They imagine that individuals could satisfy their need and make change in the event that they work. This introduction considers how fruitful persons play out their work, and get to be good examples. This condition is meant the low innovativeness, where individuals for the most part take after other (effective) persons.

The substance of connection amongst human and time for neighborhood group could be found in the trust that human ought to take after their life time by time. They live for now and give no (or less) consideration for what's to come.

The substance of connection between human associated with human. The general population give more accentuation on themselves. This individual introduction offers route to the trust that exclusively working together will give better results contrast with the participation with others.

The embodiment of connection amongst human and nature. The people group consider the nature as most compelling for human's life. In this manner human ought to life as a major aspect of the nature and human is nothing contrast and allpowerful nature.

\section{REFERENCES}

[1] Acs, Z.J.; "How Is Entrepreneurship Good for Economic Growth?" Innovations, 1, 1, pp. 97-107, 2006.

[2] Bednarzik, R.W.; "The role of entrepreneurship in U.S. and European job growth," Monthly Labor Review, 56, 4, pp. 419 - 452, 2000.

[3] Bekkers, R.; "Stability, reliability and validity of social value orientation," unpublished.

[4] Bosma, N., Z.J. Acs, E. Autio, A. Coduras, and J. Levie, GEM 2008 Executive Report, 2009.

[5] Davidsson, P.; Researching Entrepreneurship. Springer, 2005

[6] Denzin, K. N.; Interpretive Ethnography, London : Sage Publication, 1996

[7] Geertz, C.; The Interpretation of Culture, New York: Basic Book, 1973

[8] Guijt, I. and J. Woodhill, Managing for Impact in Rural Development: A guide for project $\mathrm{M} \& \mathrm{E}$. International Fund for Agricultural Development, Rome, Italy, 2002.

[9] Jones, C. and J. English; "A contemporary approach to entrepreneurship education," Education and Training, 46, 8/9, pp. 416-423, 2004.

[10] Kirzner, I.; Competition and Entrepreneurship. University of Chicago Press, 1973.

[11] Koentjaraningrat; Metode Penelitian Masyarakat, Jakarta: Gramedia, 1990. (In Bahasa Indonesia)

[12] Kompas Daily, "MSMEs need Rp 598.6 trillions," printed at May 12, 2009. (In Bahasa Indonesia)

[13] Larso, D., Yulianto, S. Rustiadi, and L. Aldianto, "Developing Technopreneurship Program at the Center for Innovation, Entrepreneurship, and Leadership (CIEL), School of Business and Management (SBM), Bandung Institute of Technology (ITB), Indonesia" in Papers presented at PICMET'99 [CD-ROM], eds.: D.F. Kocaoglu, T.R. Anderson, T.U. Daim, A. Jetter and C.M. Webber, Portland, OR: PICMET, August 2009.

[14] Rudito, B. and M. Famiola; Social Mapping, Bandung: Rekayasa Sain, 2008.

[15] Spradley, J. M (ed).; Culture and Cognition: Rules, Maps and Plans, Chandler Publishing Company, 1972.

[16] Spradley, J. M; Participant Observation, New York, 1996. 